\section{Propagation and Establishment of Three Endangered Mexican Orchids from Protocorms}

\author{
Martín Mata-Rosas ${ }^{1}$ and Víctor M. Salazar-Rojas \\ Instituto de Ecologia, A.C., Unidad de Recursos Forestales, Km 2.5 carretera \\ antigua a Coatepec 350, Xalapa, Veracruz 91070, Mexico
} Additional index words. micropropagation, protocorm-like bodies, ex vitro establishment,
conservation

\begin{abstract}
Protocols for in vitro propagation from protocorms of Mormodes tuxtlensis Salazar, Cuitlauzina pendula La Llave \& Lex., and Lycaste skinneri (Batem. Ex. Lind.) Lind., three endangered species distributed in Mexico and highly appreciated as ornamentals, were developed. The effect of two different culture media, Murashige and Skoog (MS) and modified Knudson $(\mathrm{KCm})$, combined with varying concentrations of $\mathrm{N}^{6}$-benzyladenine $(0,2.2,4.4,8.9$, and $13.3 \mu \mathrm{M})$ and $\alpha$-naphthaleneacetic acid $(0,0.5$ and $2.7 \mu \mathrm{M})$, were investigated. Shoot formation and development of protocorm-like bodies were observed. For all three species, cultures in MS produced more shoots per explant than those in $\mathrm{KCm}$, and those shoots were longer and more robust in appearance. Maximum number of shoots for $M$. tuxtlensis (1.5) and $C$. pendula (24.3) were obtained in media supplemented with $13.3 \mu \mathrm{M}$ and $2.2 \mu \mathrm{M} \mathrm{N}^{6}$-benzyladenine, respectively. Conversely, for $L$. skinneri the greatest shoot production (16.4) was achieved in medium supplemented with $2.7 \mu M \alpha$-naphthaleneacetic acid. Subculturing explants in MS basal medium allowed further development and rooting of the shoots as well as growth of protocorm-like bodies. The effect of different potting mixes on ex vitro survival plantlets was also investigated; pine bark:oak charcoal:pumice $(3: 1: 1)$ allowed the highest survival rates in all three species.
\end{abstract}

Mexico has $\approx 1200$ of the 25,000 orchid species that have been described (Dixon et al., 2003); $40 \%$ of these are endemic species (Espejo and López, 1998). Several species are endangered as a direct or indirect result of two human activities: habitat alteration and overcollecting (Flores-Palacios and Valencia-Díaz, 2007; IUCN/SSC Orchid Specialist Group, 1996). One hundred seventy-nine orchid species are protected by the Mexican government and research aimed at finding new methods to conserve and propagate these species is a high priority. Among these are three highly sought-after species: Mormodes tuxtlensis, Cuitlauzina pendula, and Lycaste skinneri.

Mormodes tuxtlensis Salazar is an epiphytic species first described in 1988. It is endemic to Mexico and grows in small areas of the tropical rain forest in Veracruz, Oaxaca, and Chiapas (Fig. 1A) (Salazar, 1988). Cuitlauzina pendula La Llave \& Lexarza is an epiphytic species endemic to the southern and western parts of Mexico (Fig. 2A). Its native range has been reduced, and the size of the type population has

\footnotetext{
Received for publication 5 June 2008. Accepted for publication 16 Apr. 2009.

We thank Pamela Moon, Philip J. Brewster, and Guillermo Angeles for the suggestions and corrections of the English text. Víctor Salazar thanks Instituto de Ecología, A.C. for the grant offered to conduct his professional studies.

${ }^{1}$ To whom reprint requests should be addressed; e-mailmartin.mata@inecol.edu.mx.
}

plummeted (Jiménez et al., 1998). Lycaste skinneri (Batem. Ex. Lind.) Lind. is an epiphytic, lithophytic, or sometimes terrestrial species that occurs from Mexico to Guatemala and Honduras (Fig. 3A) (Jiménez et al., 1998). In recent years, this species has not been reported from Mexico, suggesting that it may be locally extinct.

Efficient in situ conservation of threatened or endangered species has proven difficult to achieve; however, ex situ conservation can complement global conservation strategies. Plant tissue culture represents an excellent option for the propagation and conservation of endangered species (Gangaprasad et al., 1999; Ket et al., 2004; Rubluo et al., 1993).

Although micropropagation of orchids has been a recognized technique for many decades (Arditti and Ernst, 1993), its use has been largely confined to species and hybrids of the genera Phalaenopsis, Cattleya, and Oncidium (Arditti and Ernst, 1993; Chen et al., 1999, 2000; Chen and Chang, 2001; Tokuhara and Mii, 2001; Wu et al., 2004). Reports of successful propagation of wild Mexican species are rare. Germination and development protocols for three Mexican species, Cattleya aurantica, Encyclia chacanoensis, and Brassavola nodosa were described by Damon et al. (2004). SantosHernández et al. (2005) reported high in vitro germination rates as well as bud and protocorm-like body (PLB) formation for Laelia albida, whereas Lee-Espinosa et al. (2007) reported the germination and organogenic proliferation of $L$. anceps ssp. dawsonii.
Ávila-Díaz and Oyama (2002) also reported in vitro germination of Laelia speciosa.

The present study describes the effect of modified Knudson $\mathrm{C}$ medium $(\mathrm{KCm})$ and Murashige and Skoog medium (MS) as well as the action of different concentrations of $\mathrm{N}^{6}$ benzyladenine (BA) and $\alpha$-naphthaleneacetic acid (NAA) on the induction of shoots and PLBs from protocorms and also the survival of ex vitro plantlets.

\section{Materials and Methods}

Seeds of the three species were donated to the Francisco Javier Clavijero Botanical Garden. Open, ripe capsules (obtained from hand-pollination) were dried for 24 to $48 \mathrm{~h}$ at $25{ }^{\circ} \mathrm{C}$. The seeds were then extracted and stored in paper envelopes inside jars over silica gel for 15 to $30 \mathrm{~d}$ at $4{ }^{\circ} \mathrm{C}$ before experimentation.

Seed surface sterilization. The seeds were placed in a filter paper envelope (Whatman No. 1, $110 \mathrm{~mm}$ diameter). The envelopes were submerged in sterile distilled water for $30 \mathrm{~min}$, then dipped in $70 \%(\mathrm{v} / \mathrm{v})$ ethanol for $1 \mathrm{~min}$, and then soaked in $30 \%(\mathrm{v} / \mathrm{v}) \mathrm{com}-$ mercial bleach solution $(1.8 \% \mathrm{NaOCl})$ with two drops of Tween-80 per $100 \mathrm{~mL}$ (Sigma, St. Louis, MO) for $30 \mathrm{~min}$. This was followed by four rinses with distilled sterilized water under aseptic conditions. The seeds were then sown in $125-\mathrm{mL}$ baby food jars containing 25 $\mathrm{mL}$ of $\mathrm{KCm}$ (Knudson, 1946) supplemented with $37.3 \mathrm{mg} \cdot \mathrm{L}^{-1} \mathrm{Na}_{2}$ EDTA and $27.8 \mathrm{mg} \cdot \mathrm{L}^{-1}$ $\mathrm{FeSO}_{4} 7 \mathrm{H}_{2} \mathrm{O}$ (Murashige and Skoog, 1962) plus $20 \mathrm{~g} \cdot \mathrm{L}^{-1}$ sucrose.

The $\mathrm{pH}$ of all culture media was adjusted to $5.0 \pm 0.1$ with $0.5 \mathrm{~N} \mathrm{NaOH}$ and $0.5 \mathrm{~N} \mathrm{HCl}$ before adding $5.5 \mathrm{~g} \cdot \mathrm{L}^{-1}$ Agargel $^{\mathrm{TM}}$ (Sigma, St. Louis, MO) and autoclaving at $1.2 \mathrm{~kg} \cdot \mathrm{cm}^{-2}$ and $120{ }^{\circ} \mathrm{C}$ for $15 \mathrm{~min}$. All cultures were incubated in a growth chamber at $25 \pm 1{ }^{\circ} \mathrm{C}$ under a $16-\mathrm{h}$ photoperiod provided by coolwhite fluorescent lamps $\left(50 \mu \mathrm{mol} \cdot \mathrm{m}^{-2} \cdot \mathrm{s}^{-1}\right)$.

Protocorm culture. After germination, protocorms with a height of 2 to $3 \mathrm{~mm}$ were selected and transferred to two different treatment media: 1) MS medium with 2 $\mathrm{mg} \cdot \mathrm{L}^{-1}$ glycine, $100 \mathrm{mg} \cdot \mathrm{L}^{-1}$ myoinositol, and $30 \mathrm{~g} \cdot \mathrm{L}^{-1}$ sucrose; and 2) $\mathrm{KCm}$. Both media were supplemented with a combination of $\mathrm{BA}(0,2.2,4.4,8.9$, or $13.3 \mu \mathrm{M})$ and NAA $(0,0.5$, and $2.7 \mu \mathrm{M})$; three protocorms were cultured in each jar. There were with 10 replicates (i.e., 30 protocorms per treatment). The induction period was $120 \mathrm{~d}$.

After the induction period, the protocorms were subcultured every $60 \mathrm{~d}$ to their respective basal medium without plant growth regulators (PGRs). The number of shoots per protocorm, shoot height, and PLB production were recorded.

Number of shoots per protocorm and shoot height were analyzed using one-way analysis of variance followed by a least significant difference test $(P \leq 0.05)$.

Ex vitro culture. Plantlet survival was assessed using individuals that had attained a height of 3 to $5 \mathrm{~cm}$ and were at least 10 months old. In the case of M. tuxtlensis, the 

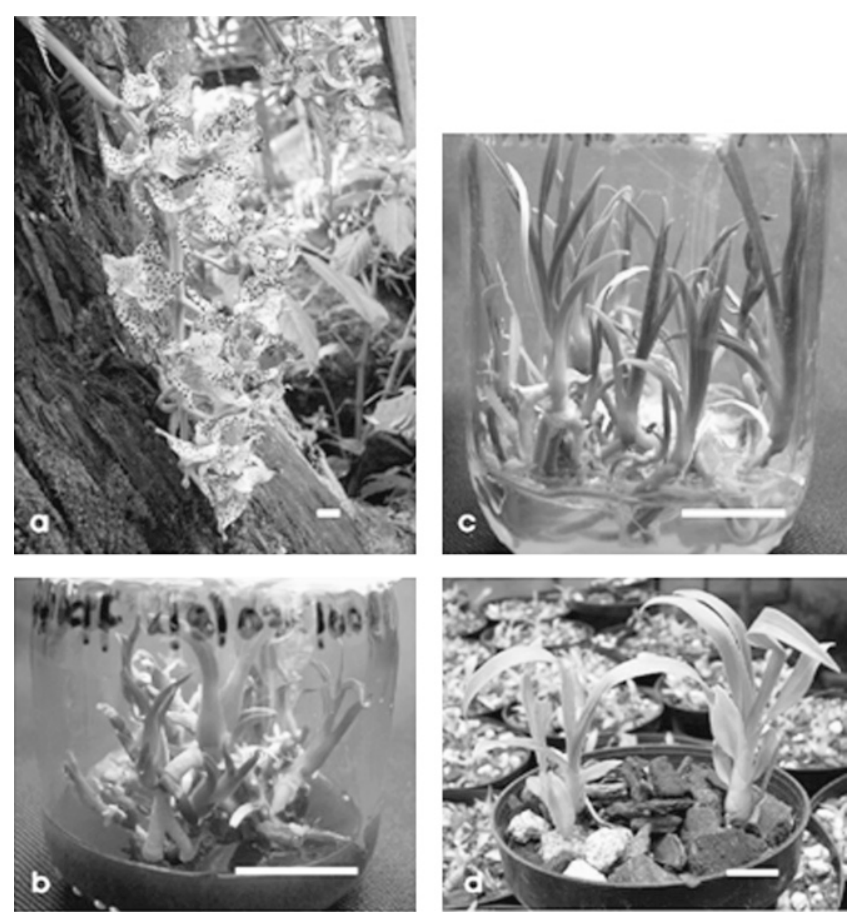

Fig. 1. Plant regeneration of Mormodes tuxtlensis through direct shoot formation. (A) Flowering plant. (B) Multiple shoot formation from protocorms in Murashige and Skoog medium $+13.3 \mu \mathrm{M} \mathrm{N}^{6}-$ benzyladenine. (C) In vitro-rooted shoots ready for ex vitro culture. (D) Plants obtained from in vitro culture after 4 months in potting mix. Bars $=2 \mathrm{~cm}$.
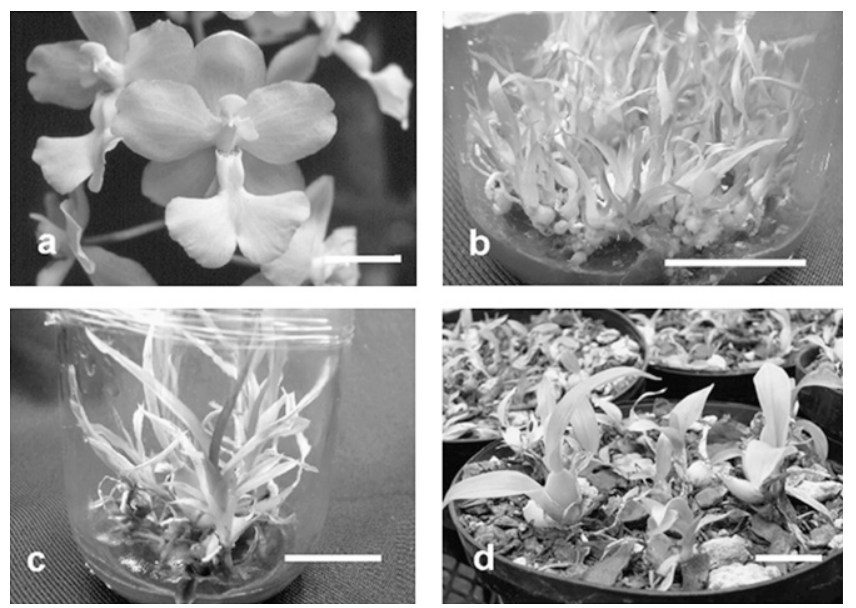

Fig. 2. Plant regeneration of Cuitlauzina pendula through direct shoot formation and protocorm-like bodies (PLBs). (A) Closeup of the flower. (B) Multiple shoot formation from protocorms in Murashige and Skoog medium $+2.2 \mu \mathrm{M} \mathrm{N}^{6}$-benzyladenine. (C) In vitro-rooted shoots ready for ex vitro culture. (D) Plants obtained from in vitro culture after 4 months in potting mix. Bars $=2 \mathrm{~cm}$.

plantlets used were smaller, ranging from 1 to $2 \mathrm{~cm}$ depending on the treatment they were previously given. The plantlets were removed from the jars, washed thoroughly under tap water to remove all adhering culture medium, then transferred to propagation trays (Hummert International, Earth City, $\mathrm{MO})$ and placed in a greenhouse with an average temperature of $30^{\circ} \mathrm{C}$. For the first 30 $\mathrm{d}$, a high relative humidity $(80 \%$ to $90 \%)$ was maintained by keeping the trays covered with plastic, translucent lids. The relative humid- ity was then decreased to $50 \%$ to $60 \%$. Three different substrates were used: 1) pumice; 2) pine bark, oak charcoal, and pumice $(3: 1: 1)$; and 3) shredded long tree-fern fiber. Survival of plantlets and their height were recorded for 4 months.

\section{Results}

\section{Germination}

For M. tuxtlensis and C. pendula, germination was first observed 100 to $120 \mathrm{~d}$ after plating; for L. skinneri; it began between 70 to $90 \mathrm{~d}$. The germination rate approached $100 \%$ for all three species, because in the different observations under stereomicroscopy, the number of nongerminated seeds was null; but in some cases, the density of seeds was too high making it impossible to affirm that $100 \%$ of seeds had already germinated.

\section{Mormodes tuxtlensis}

Organogenesis and shoot formation. Seventy-one percent of protocorms cultured in $\mathrm{KCm}$ grew and began to form shoots. In contrast, only $61 \%$ of protocorms cultured in MS showed any morphogenic response. Those that did not respond turned brown.

Shoots, formed through direct organogenesis from protocorms that had developed rhizoids and leaves, were 5 to $8 \mathrm{~mm}$ long. After $90 \mathrm{~d}$, small nodules formed mainly at the base of the protocorms. These nodules started to produce leaf primordial $\approx 30 \mathrm{~d}$ later, especially in the $\mathrm{KCm}$ treatments; after the protocorms were subcultured to basal medium, the nodules consolidated into adventitious shoots (Fig. 1B).

Shoot formation per protocorm differed significantly among treatments $(P \leq 0.0001)$. Although not significantly different from several other treatments, the highest level of shoot formation ( 1.5 shoots per protocorm) was achieved in the MS medium treatment supplemented with BA $(13.3 \mu \mathrm{M}) ; 1.4$ shoots per protocorm developed from explants cultured in MS medium BA $(8.9 \mu \mathrm{M})$ either alone or in combination with $2.7 \mu \mathrm{M}$ NAA. In these three treatments, $85 \%$ of protocorms showed some morphogenetic response (Table 1A). In MS medium, in most cases, shoot formation tended to occur in treatments containing at least BA $(4.4 \mu \mathrm{M})$.

Although statistically significant differences could not be established among $\mathrm{KCm}$ treatments, the most shoot formation per protocorm (1.4) and highest percent of responding protocorms (93\% to $100 \%)$ were obtained in the three treatments: BA (4.4 $\mu \mathrm{M}), \mathrm{BA} / \mathrm{NAA}(2.2 / 0.5 \mu \mathrm{M})$, and NAA $(0.5$ $\mu \mathrm{M})$ (Table 1A). In all other treatments, fewer than $76.6 \%$ of the explants responded.

Height. Table 1A shows that shoot height from the MS treatments ranged from 1.5 to $2.9 \mathrm{~cm}$ and significant differences $(P=$ 0.0001 ) could be established between them. Shoots from the different $\mathrm{KCm}$ treatments had statistically significant different heights $(P=0.0012)$, and these were slightly greater than those developed in MS, ranging from 1.8 to $3 \mathrm{~cm}$ (Fig. 1C).

Ex vitro survival. Plantlets of $M$. tuxtlensis obtained from the $\mathrm{KCm}$ treatments did not survive after outplanting; in contrast, $78 \%$ of plantlets from MS tolerated ex vitro culture (Fig. 1D). Percentage of survival varied with substrate used; there was an $89 \%$ survival rate from the pine bark:oak charcoal:pumice treatment, whereas only $75 \%$ of plantlets placed in the other substrates survived. 

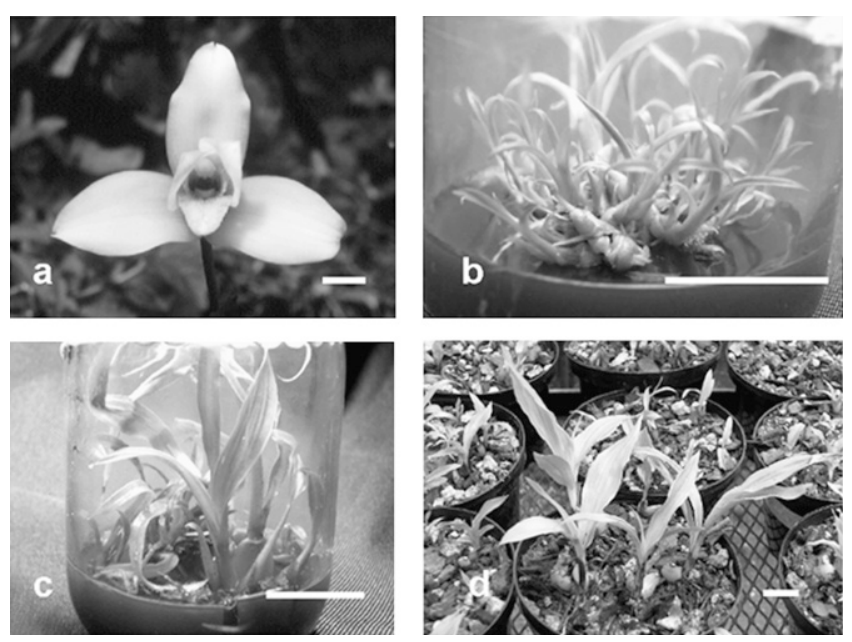

Fig. 3. Plant regeneration of Lycaste skinneri through direct shoot formation (A) Flowering plant. (B) Multiple shoot formation from protocorms in Murashige and Skoog medium $+2.7 \mu \mathrm{M}$ $\alpha$-naphthaleneacetic acid. (C) In vitro-rooted shoots ready for ex vitro culture. (D) Plants obtained from in vitro culture after 4 months in potting mix. Bars $=2 \mathrm{~cm}$.

\section{Cuitlauzina pendula}

Organogenesis. Percentage of responding explants in most treatments from both culture media (MS and $\mathrm{KCm}$ ) was $\approx 100 \%$, and PLB formation was the main response in all treatments.

In protocorms cultured in different MS medium treatments, PLB formation started after $30 \mathrm{~d}$ of culture. The protocorms increased their size and acquired a wrinkled green surface with nodular protuberances. After $120 \mathrm{~d}$, nodules were consolidated into small shoots and then into plantlets in which the root development and leaf primordial were evident. After the PLBs were subcultured, they increased their height, eventually forming pseudobulbs that eventually consolidated into plantlets (Fig. 2B). More than $50 \%$ of the new plantlets formed secondary PLBs; these originated mainly from the base of the pseudobulb.

PLB formation from protocorms cultured in $\mathrm{KCm}$ medium took more time than those in MS treatments; the development of nodules were perceptible after 60 to $120 \mathrm{~d}$, and the consolidation of few nodules in PLBs was obtained after few monthly subcultures to $\mathrm{KCm}$ basal medium, but all of them were pale green in color. The conversion of PLBs into plantlets was achieved after 6 months; however, some of them retained this stage during the entire experiment.

Shoot formation differed significantly among MS treatments $(P=0.0001)$. The highest average number (24.3) of shoots was recorded in the treatment containing BA $(2.2 \mu \mathrm{M})$; in the rest of the treatments, a lower average was registered (Table 1B).

Plantlets obtained using $\mathrm{KCm}$ medium treatments showed statistically significant differences between different treatments $(P=$ $0.0001)$. A higher average number (28.8) of shoots per explant was obtained in treatment containing BA/NAA $(13.3 / 0.5 \mu \mathrm{M})$. In treatments supplemented with higher concentrations of BA ( 8.9 and $13.3 \mu \mathrm{M})$ in combination with high NAA concentrations $(2.7 \mu \mathrm{M})$, it was also possible to induce a large number of plantlets per explant, achieving a production average of 26.5 and 24.8 plantlets per explant, respectively.

Height. Plantlets from MS medium were higher than those obtained using $\mathrm{KCm}$ (Fig. 2C). In both media, plantlet height was influenced by PGR treatments, and it was possible to establish statistically significant differences $(P<0.05)$. Plantlets attained an average height of $3 \mathrm{~cm}$ in the PGR-free MS medium as well as the ones supplemented with BA/NAA (4.4/0.5 and 4.4/2.7 $\mu \mathrm{M})$ (Table 1B).

In $\mathrm{KCm}$ medium, a higher average height was also obtained from the treatment without PGR $(1.7 \mathrm{~cm})$, whereas the treatments including BA/NAA $(4.4 / 2.7 \mu \mathrm{M})$ and BA $(2.2 \mu \mathrm{M})$ showed average heights of 1.4 and $1.3 \mathrm{~cm}$, respectively (Table 1B).

Ex vitro survival. Plantlets from the different treatments assayed with MS showed $67 \%$ survival (Fig. 2D), whereas for $\mathrm{KCm}$ only $2.7 \%$ of the plantlets survived.

The survival of plantlets was affected by different substrates used to culture them ex vitro. Plantlets from MS reached $76 \%$ survival with the soil mix followed by pumice with $72 \%$, and finally using shredded long tree-fern fiber $53 \%$ of the plantlets survived. From $\mathrm{KCm}$, the highest plantlet survival of $4.1 \%$ was obtained with the soil mix, $2.4 \%$ with pumice, and $1.5 \%$ with the shredded long tree-fern fiber.

\section{Lycaste skinneri}

Organogenesis. High percentages of response (growth and development) were obtained in both culture media used, MS $(91.3 \%)$ and $\mathrm{KCm}(88.1 \%)$. The main morphogenetic response obtained was the shoot formation through direct organogenesis (Fig. 3B). After subculturing the explants in their respective basal media, the shoots increased their height and developed roots. Occasion- ally, in a few treatments from KCm, PLB formation was observed.

During the first $30 \mathrm{~d}$ in MS medium, the protocorms increased their volume approximately three to six times and retained a pale green coloration. During the next $30 \mathrm{~d}$, small shoots or small green leaf primordia appeared around the explant. Afterward, each shoot continued its growth and formed well-consolidated leaves; in a few cases, it was possible to observe small roots with velamen. Despite the shoots having developed roots, they remained joined to the original explant.

In $\mathrm{KCm}$, the shoot formation and development were slower than MS cultures. The growth of protocorms was not evident until $60 \mathrm{~d}$; they increased approximately two to three times their original size. Shoot formation was not achieved until the protocorms were subcultured to $\mathrm{KCm}$ basal media.

Shoot formation per protocorm differed significantly among treatments $(P=0.0001)$. Plantlet formation was favored by highest NAA concentrations $(2.7 \mu \mathrm{M})$ either alone or in combination with low concentrations of BA (Table 1C). The highest shoot formation (16.4) was obtained in MS medium treatment supplemented with NAA $(2.7 \mu \mathrm{M})$ followed by treatment with BA/NAA $(2.2 / 2.7 \mu \mathrm{M})$ and BA/NAA $(8.9 / 0.5 \mu \mathrm{M})$, in which 14.8 and 13.3 shoots per explant were obtained, respectively (Table $1 \mathrm{C}$ ).

A statistically significant difference for shoot formation among $\mathrm{KCm}$ treatments could not be established; however, it was possible to observe that treatments with $\mathrm{BA}$ / NAA $(0 / 0.5$ and $0.5 / 2.2 \mu \mathrm{M})$ stimulated higher shoot formation (Table 1C).

Height. Shoots obtained from all MS treatments attained a greater height than those produced from $\mathrm{KCm}$. Media supplemented with $2.7 \mu \mathrm{M}$ NAA tended to have the tallest plantlets with the greatest average height $(3.7 \mathrm{~cm})$ obtained from MS supplemented with BA/NAA $(4.4 / 2.7 \mu \mathrm{M})$ (Fig. $3 \mathrm{C})$. For $\mathrm{KCm}$, shoots with an average height of $4 \mathrm{~cm}$ were obtained from media supplemented with BA/NAA $(13.3 / 2.7 \mu \mathrm{M})$.

Ex vitro survival. As observed for preceding species, ex vitro survival of the plantlets of L. skinneri was also influenced by culture media. Those from MS showed high vigor and $50.4 \%$ survival (Fig. 3D); for $\mathrm{KCm}$, only $4.7 \%$ of the plantlets survived.

Survival of plantlets from MS was greatest $(60.1 \%)$ in the pine bark, oak charcoal, and pumice mix followed by shredded long tree-fern fiber $(48.2 \%)$ and then pumice (42.7\%).

Percentage plantlet survival from $\mathrm{KCm}$ was very low. The pine bark, oak charcoal, and pumice mix allowed $6.5 \%$ survival. A total of $5.7 \%$ of plantlets grown in shredded tree-fern fiber survived, whereas survival in pumice was only $1.7 \%$.

\section{Discussion}

Orchid seeds can germinate on a wide variety of culture media in a relatively short period of time (Yam and Weatherhead, 1988) 
Table 1. Effect of media and plant growth regulators (BA and NAA) on the induction of shoots and their final height from in vitro culture of protocorms of (A) Mormodes tuxtlensis, (B) Cuitlauzina pendula, and (C) Lycaste skinneri.

\begin{tabular}{|c|c|c|c|c|c|c|c|}
\hline \multicolumn{8}{|c|}{ (A) Mormodes tuxtlensis } \\
\hline \multirow{2}{*}{\multicolumn{2}{|c|}{ PGR $(\mu \mathrm{M})$}} & \multicolumn{3}{|c|}{ Murashige and Skoog } & \multicolumn{3}{|c|}{ Knudson C (mod.) } \\
\hline & & \multirow{2}{*}{$\begin{array}{l}\text { Responding } \\
\text { explants }(\%)\end{array}$} & \multirow{2}{*}{$\begin{array}{c}\text { Shoots per } \\
\text { explant }^{z}\end{array}$} & \multirow[b]{2}{*}{ Shoot heightz } & \multirow{2}{*}{$\begin{array}{l}\text { Responding } \\
\text { explants }(\%)\end{array}$} & \multirow{2}{*}{$\begin{array}{c}\text { Shoots per } \\
\text { explant }^{z}\end{array}$} & \multirow[b]{2}{*}{ Shoot height ${ }^{z}$} \\
\hline $\mathrm{BA}$ & $\overline{\mathrm{NAA}}$ & & & & & & \\
\hline 0 & 0 & 40.0 & $0.7 \pm 0.2 \mathrm{a}$ & $2.6 \pm 0.3 \mathrm{cdef}$ & 66.0 & $0.9 \pm 0.2$ & $1.9 \pm 0.2 \mathrm{ab}$ \\
\hline 2.2 & 0 & 50.0 & $0.8 \pm 0.2 \mathrm{ab}$ & $1.5 \pm 0.2 \mathrm{a}$ & 76.6 & $1.2 \pm 0.2$ & $1.8 \pm 0.2 \mathrm{a}$ \\
\hline 4.4 & 0 & 90.0 & $1.3 \pm 0.1$ bcde & $2.7 \pm 0.2 \mathrm{def}$ & 93.3 & $1.4 \pm 0.2$ & $2.0 \pm 0.2 \mathrm{abcd}$ \\
\hline 8.9 & 0 & 85.0 & $1.4 \pm 0.1 \mathrm{cde}$ & $2.3 \pm 0.2 \mathrm{cde}$ & 70.0 & $1.1 \pm 0.2$ & $2.1 \pm 0.2 \mathrm{abcd}$ \\
\hline 13.3 & 0 & 85.0 & $1.5 \pm 0.2 \mathrm{e}$ & $2.9 \pm 0.2 \mathrm{f}$ & 76.6 & $1.0 \pm 0.1$ & $2.2 \pm 0.2 \mathrm{abcd}$ \\
\hline 0 & 0.5 & 90.0 & $1.3 \pm 0.1$ bcde & $2.2 \pm 0.2 \mathrm{cde}$ & 93.3 & $1.4 \pm 0.2$ & $1.9 \pm 0.2 \mathrm{a}$ \\
\hline 2.2 & 0.5 & 45.0 & $0.8 \pm 0.2 \mathrm{a}$ & $2.1 \pm 0.2 \mathrm{abc}$ & 100.0 & $1.4 \pm 0.1$ & $2.2 \pm 0.2 \mathrm{abcd}$ \\
\hline 4.4 & 0.5 & 57.5 & $0.9 \pm 0.2 \mathrm{abc}$ & $2.7 \pm 0.2 \mathrm{def}$ & 70.0 & $1.0 \pm 0.2$ & $2.5 \pm 0.3$ bcdef \\
\hline 8.9 & 0.5 & 57.5 & $1.0 \pm 0.2 \mathrm{abcd}$ & $2.1 \pm 0.2 \mathrm{bcd}$ & 70.0 & $1.2 \pm 0.2$ & $3.0 \pm 0.2 \mathrm{f}$ \\
\hline 13.3 & 0.5 & 52.5 & $1.0 \pm 0.2 \mathrm{abcd}$ & $2.5 \pm 0.1 \mathrm{cdef}$ & 53.0 & $0.7 \pm 0.2$ & $2.9 \pm 0.3 \mathrm{ef}$ \\
\hline 0 & 2.7 & 60.0 & $0.9 \pm 0.1 \mathrm{ab}$ & $1.6 \pm 0.2 \mathrm{ab}$ & 56.6 & $1.0 \pm 0.2$ & $2.2 \pm 0.2$ abcde \\
\hline 2.2 & 2.7 & 50.0 & $0.8 \pm 0.2 \mathrm{ab}$ & $2.2 \pm 0.2$ bcde & 73.3 & $1.2 \pm 0.2$ & $2.6 \pm 0.3 \mathrm{def}$ \\
\hline 4.4 & 2.7 & 47.5 & $0.9 \pm 0.2 \mathrm{abc}$ & $1.5 \pm 0.1 \mathrm{a}$ & 63.3 & $0.8 \pm 0.1$ & $2.6 \pm 0.4 \mathrm{cdef}$ \\
\hline 8.9 & 2.7 & 85.0 & $1.4 \pm 0.2 \mathrm{de}$ & $2.7 \pm 0.2$ ef & 56.6 & $1.1 \pm 0.3$ & $2.2 \pm 0.2 \mathrm{abcd}$ \\
\hline 13.3 & 2.7 & 65.0 & $1.1 \pm 0.2$ abcde & $2.5 \pm 0.2$ cdef & 53.3 & $0.9 \pm 0.2$ & $1.9 \pm 0.2 \mathrm{abc}$ \\
\hline \multicolumn{8}{|c|}{ (B) Cuitlauzina pendula } \\
\hline \multirow{2}{*}{\multicolumn{2}{|c|}{ PGR $(\mu \mathrm{M})$}} & \multicolumn{3}{|c|}{ Murashige and Skoog } & \multicolumn{3}{|c|}{ Knudson C (mod.) } \\
\hline & & \multirow{2}{*}{$\begin{array}{l}\text { Responding } \\
\text { explants }(\%)\end{array}$} & \multirow{2}{*}{$\begin{array}{c}\text { Shoots per } \\
\text { explant }\end{array}$} & \multirow[b]{2}{*}{ Shoot height $^{z}$} & Responding & Shoots per & \\
\hline $\mathrm{BA}$ & NAA & & & & explants $(\%)$ & explant ${ }^{\mathrm{z}}$ & Shoot height ${ }^{z}$ \\
\hline 0 & 0 & 100.0 & $14.8 \pm 5.1 \mathrm{~d}$ & $3.0 \pm 0.1 \mathrm{i}$ & 97.1 & $5.7 \pm 1.0 \mathrm{a}$ & $1.7 \pm 0.1 \mathrm{f}$ \\
\hline 2.2 & 0 & 99.0 & $24.3 \pm 5.1 \mathrm{e}$ & $2.4 \pm 0.1$ bcde & 97.8 & $9.1 \pm 1.2 \mathrm{ab}$ & $1.3 \pm 0.0 \mathrm{e}$ \\
\hline 4.4 & 0 & 97.0 & $9.7 \pm 2.0 \mathrm{abcd}$ & $2.6 \pm 0.1 \mathrm{cdef}$ & 96.2 & $14.0 \pm 2.0 \mathrm{bcd}$ & $1.0 \pm 0.0 \mathrm{~b}$ \\
\hline 8.9 & 0 & 93.0 & $2.5 \pm 1.0 \mathrm{a}$ & $2.1 \pm 0.1 \mathrm{ab}$ & 97.8 & $10.4 \pm 1.5 \mathrm{abc}$ & $1.2 \pm 0.0 \mathrm{~d}$ \\
\hline 13.3 & 0 & 100.0 & $15.5 \pm 4.9 \mathrm{~d}$ & $2.0 \pm 0.1 \mathrm{a}$ & 97.5 & $20.1 \pm 2.8 \mathrm{defg}$ & $1.0 \pm 0.0 \mathrm{~b}$ \\
\hline 0 & 0.5 & 99.0 & $6.9 \pm 1.6 \mathrm{abcd}$ & $2.3 \pm 0.1 \mathrm{bc}$ & 97.0 & $8.6 \pm 1.7 \mathrm{ab}$ & $1.2 \pm 0.0 \mathrm{~cd}$ \\
\hline 2.2 & 0.5 & 100.0 & $12.3 \pm 1.8 \mathrm{~cd}$ & $2.2 \pm 0.1 \mathrm{~b}$ & 94.8 & $16.6 \pm 2.5 \mathrm{cde}$ & $1.0 \pm 0.0 \mathrm{~b}$ \\
\hline 4.4 & 0.5 & 83.0 & $3.3 \pm 1.6 \mathrm{abcd}$ & $3.0 \pm 0.2 \mathrm{hi}$ & 97.2 & $9.2 \pm 1.5 \mathrm{ab}$ & $1.1 \pm 0.0 \mathrm{~cd}$ \\
\hline 8.9 & 0.5 & 100.0 & $8.6 \pm 2.1 \mathrm{abcd}$ & $2.7 \pm 0.1 \mathrm{efgh}$ & 100.0 & $16.3 \pm 2.8 \mathrm{~cd}$ & $1.1 \pm 0.0 \mathrm{c}$ \\
\hline 13.3 & 0.5 & 96.0 & $4.4 \pm 1.5 \mathrm{abc}$ & $2.1 \pm 0.1 \mathrm{ab}$ & 97.7 & $28.8 \pm 3.4 \mathrm{~h}$ & $0.9 \pm 0.0 \mathrm{a}$ \\
\hline 0 & 2.7 & 96.0 & $4.5 \pm 0.9 \mathrm{abc}$ & $2.3 \pm 0.1 \mathrm{bcd}$ & 99.4 & $23.4 \pm 3.7 \mathrm{efgh}$ & $1.0 \pm 0.0 \mathrm{~b}$ \\
\hline 2.2 & 2.7 & 78.0 & $7.3 \pm 3.2 \mathrm{abcd}$ & $2.4 \pm 0.1$ bcde & 97.3 & $18.5 \pm 2.7 \mathrm{def}$ & $1.0 \pm 0.0 \mathrm{~b}$ \\
\hline 4.4 & 2.7 & 95.0 & $8.5 \pm 3.9 \mathrm{abcd}$ & $2.9 \pm 0.1 \mathrm{ghi}$ & 99.0 & $9.5 \pm 1.4 \mathrm{ab}$ & $1.4 \pm 0.0 \mathrm{e}$ \\
\hline 8.9 & 2.7 & 99.0 & $13.6 \pm 3.0 \mathrm{~d}$ & $2.7 \pm 0.1 \mathrm{fg}$ & 98.6 & $26.5 \pm 3.6 \mathrm{gh}$ & $1.0 \pm 0.0 \mathrm{~b}$ \\
\hline 13.3 & 2.7 & 98.0 & $1.4 \pm 3.8 \mathrm{bcd}$ & $2.6 \pm 0.1 \mathrm{defg}$ & 99.1 & $24.8 \pm 2.2 \mathrm{fgh}$ & $0.8 \pm 0.0 \mathrm{a}$ \\
\hline & & & & Lycaste skinneri & & & \\
\hline & & & Murashige and Sko & & & Knudson C (mod & \\
\hline & & Responding & Shoots per & & Responding & Shoots per & \\
\hline $\mathrm{BA}$ & $\overline{\mathrm{NAA}}$ & explants $(\%)$ & explant ${ }^{\mathrm{z}}$ & Shoot height ${ }^{z}$ & explants $(\%)$ & explant $^{\mathrm{z}}$ & Shoot height $^{z}$ \\
\hline 0 & 0 & 80.2 & $2.3 \pm 0.7 \mathrm{a}$ & $2.5 \pm 0.1 \mathrm{abc}$ & 100.0 & $7.7 \pm 2.0$ & $2.1 \pm 0.1 \mathrm{bcde}$ \\
\hline 2.2 & 0 & 82.9 & $2.1 \pm 0.7 \mathrm{a}$ & $3.0 \pm 0.1$ bcde & 97.9 & $7.8 \pm 1.5$ & $2.0 \pm 0.1$ bcde \\
\hline 4.4 & 0 & 100.0 & $3.4 \pm 1.8 \mathrm{a}$ & $2.1 \pm 0.2 \mathrm{a}$ & 92.8 & $9.8 \pm 2.4$ & $1.9 \pm 0.1 \mathrm{bcde}$ \\
\hline 8.9 & 0 & 96.2 & $3.5 \pm 0.7 \mathrm{a}$ & $2.9 \pm 0.2 \mathrm{bcd}$ & 89.6 & $10.6 \pm 2.7$ & $1.7 \pm 0.1 \mathrm{ab}$ \\
\hline 13.3 & 0 & 63.6 & $2.3 \pm 1.3 \mathrm{a}$ & $2.2 \pm 0.2 \mathrm{ab}$ & 84.1 & $9.1 \pm 2.2$ & $1.7 \pm 0.1 \mathrm{abc}$ \\
\hline 0 & 0.5 & 73.2 & $1.5 \pm 0.3 \mathrm{a}$ & $2.7 \pm 0.1 \mathrm{abc}$ & 86.3 & $15.3 \pm 3.3$ & $1.8 \pm 0.1 \mathrm{bcd}$ \\
\hline 2.2 & 0.5 & 88.5 & $3.0 \pm 1.0 \mathrm{a}$ & $2.7 \pm 0.1 \mathrm{abc}$ & 95.1 & $11.3 \pm 1.9$ & $1.8 \pm 0.1 \mathrm{bcd}$ \\
\hline 4.4 & 0.5 & 85.7 & $3.1 \pm 0.9 \mathrm{a}$ & $2.5 \pm 0.2 \mathrm{abc}$ & 74.4 & $10.8 \pm 2.8$ & $1.8 \pm 0.1 \mathrm{abcd}$ \\
\hline 8.9 & 0.5 & 99.5 & $13.3 \pm 3.6 \mathrm{bcd}$ & $2.6 \pm 0.1 \mathrm{abc}$ & 89.5 & $6.4 \pm 2.5$ & $1.3 \pm 0.1 \mathrm{a}$ \\
\hline 13.3 & 0.5 & 99.4 & $11.0 \pm 2.1 \mathrm{bc}$ & $3.5 \pm 0.3 \mathrm{def}$ & 92.0 & $9.3 \pm 2.8$ & $1.7 \pm 0.1 \mathrm{ab}$ \\
\hline 0 & 2.7 & 100.0 & $16.4 \pm 1.9 \mathrm{~d}$ & $3.4 \pm 0.0 \mathrm{def}$ & 93.0 & $6.4 \pm 0.8$ & $2.7 \pm 0.2 \mathrm{f}$ \\
\hline 2.2 & 2.7 & 100.0 & $14.8 \pm 1.9 \mathrm{~cd}$ & $3.6 \pm 0.1 \mathrm{f}$ & 89.4 & $11.0 \pm 1.4$ & $2.2 \pm 0.1 \mathrm{cde}$ \\
\hline 4.4 & 2.7 & 100.0 & $9.9 \pm 0.8 b$ & $3.7 \pm 0.1 \mathrm{f}$ & 87.2 & $9.8 \pm 1.4$ & $2.3 \pm 0.1 \mathrm{ef}$ \\
\hline 8.9 & 2.7 & 99.6 & $9.3 \pm 1.4 \mathrm{~b}$ & $3.6 \pm 0.1 \mathrm{ef}$ & 78.1 & $6.1 \pm 1.2$ & $2.3 \pm 0.1 \mathrm{def}$ \\
\hline 13.3 & 2.7 & 100.0 & $9.2 \pm 1.3 \mathrm{~b}$ & $3.0 \pm 0.1 \mathrm{cde}$ & 72.0 & $3.8 \pm 1.0$ & $4.0 \pm 1.3 \mathrm{~g}$ \\
\hline
\end{tabular}

${ }^{\mathrm{z}}$ Mean \pm SD. Results after 8 months. Different letters within columns indicate significant difference at $P \leq 0.05$.

$\mathrm{BA}=\mathrm{N}^{6}$-benzyladenine; NAA $=\alpha$-naphthaleneacetic acid; PGR $=$ plant growth regulator.

and $\mathrm{KCm}$ and MS are frequently used. Different responses have been reported for culture of one species on different culture media (Bhadra and Hossain, 2003). Ichihashi (1991) states that germination of orchids is best in culture media with low mineral concentration such as $\mathrm{KCm}$. In this study, $\mathrm{KCm}$ proved to be an adequate germination medium for all three species. Growth was similar, but germination time varied. $\mathrm{KCm}$ has been used for germination of several diverse orchid species
(Bhadra and Hossain, 2003; Pierik et al., 1988; Yam and Weatherhead, 1988).

Morphogenic responses were strongly affected by medium formulation and PGR. For M. tuxtlensis and L. skinneri, the main response was shoot formation; and for $C$. pendula, it was PLB formation. Fay (1994) states the requirements for in vitro culture of every single species must be determined experimentally; previously established regeneration protocols can only be applied in a general way. M. tuxtlensis and L. skinneri had different PGR concentration optima but were otherwise similar in their responses.

There are few reports with similar results as our observations with M. tuxtlensis. Mauro et al. (1994) found, for Cattleya aurantiaca, the highest shoot formation occurred in MS medium with BA/NAA (44.4/0.5 $\mu \mathrm{M})$. However, in several other orchid species, optimal results have been obtained using MS medium containing relatively high cytokinin 
concentrations and no auxins (Gangaprasad et al., 1999; Kerbauy and Collin, 1997; Ket et al., 2004; Nayak et al., 1997).

Results similar to those obtained for $L$. skinneri have been reported for other orchid species (Hernández, et al., 2001; Kusumoto, $1978,1979)$ in which the highest shoot formation was achieved in MS with a higher level of auxin and lower of cytokinin. However, it is more commonly reported that auxins have an inhibitory effect on shoot formation (Kerbauy and Collin, 1997; Pierik and Steegmans, 1972; Rubluo et al., 1993).

In contrast, PLB formation in $C$. pendula was the primary observed response, and this kind of response is not uncommon in diverse orchid genera such as Oncidium, Dendrobium, and Cymbidium (Chen et al., 1999; Saiprasad and Polisetty, 2003; Texeira da Silva et al., 2006).

For $C$. pendula, the highest average number of PLBs and shoots per explant were obtained from $\mathrm{KCm}$, but the subsequent development in $\mathrm{KCm}$ basal medium was lower than in MS; an alternative methodology for this species could be to induce shoots and PLBs in $\mathrm{KCm}$ and then subculture them into MS basal medium. It is possible that more vigorous plantlets could be obtained.

In México and other tropical countries, tree-fern fiber ("maquique") is commonly used as a substrate for orchid culture and overcollection for this purpose has contributed to many tree-ferns becoming endangered (Palacios-Rios and Flores, 1992). The present study demonstrated that "maquique" is not the best substrate for ex vitro plantlet establishment, and superior alternatives such the pine bark:oak charcoal:pumice mix used here exist. Reduction in the use of maquique could help conserve several tree-fern species.

Documented studies with Mexican orchids are scarce, and most of them focus on determination of the best culture media for the germination and development of plantlets (Damon et al., 2004; Lee-Espinosa, et al., 2007; Santos-Hernández et al., 2005). The use of protocorms as an explant is ideal for propagation, especially if the goal is to maximize genetic variability. Therefore, success in defining micropropagation protocols for these three species with high ornamental potential is one of the main contributions of the present study. Not only could this technique be used by other researchers, but also by individuals in rural communities interested in establishing nurseries to satisfy horticultural demand while reducing pressures on wild populations.

\section{Literature Cited}

Arditti, J. and R. Ernst. 1993. Micropropagation of orchids. Wiley, New York, NY

Ávila-Díaz, I. and K. Oyama. 2002. Manejo sustentable de Laelia speciosa (Orchidaceae). Biodiversitas. 7:9-12.

Bhadra, S.K. and M.M. Hossain. 2003. In vitro germination and micropropagation of Geodorum densiflorum (Lam.) Schltr., an endangered orchid species. Plant Tiss. Cult. 13:165-171.

Chen, J.T., C. Chang, and W.C. Chang. 1999. Direct somatic embryogenesis on leaf explants of Oncidium Gower Ramsey and subsequent plant regeneration. Plant Cell Rep. 19:143149.

Chen, J.T. and W.C. Chang. 2001. Effects of auxins and cytokinins on direct somatic embryogenesis on leaf explants of Oncidium 'Gower Ramsey'. Plant Growth Regulat. 34:229-232.

Chen, Y., Ch. Chang, and W. Chang. 2000. A reliable protocol for plant regeneration from callus culture of Phalaenopsis. In Vitro Cell. Dev. Biol. Plant 36:420-423.

Damon, A., E. Aguilar-Guerrero, L. Rivera, and V. Nikolaeva. 2004. Germinación in vitro de semillas inmaduras de tres especies de orquídeas de la región del Soconusco, Chiapas, México. Revista Chapingo Serie Horticultura 10:195-204

Dixon, K., S. Kell, R. Borret, and P. Cribb. 2003. Orchid conservation. Natural History Publications (Borneo), Kota Kinabalu, Sabal

Espejo, S.A. and F.A.R. López. 1998. Las Monocotiledóneas Mexicanas una Sinopsis Florística 1. Lista de Referencia Parte VII. Orchidaceae I. Consejo Nacional de la Flora de México, A.C. Universidad Autónoma Metropolitana-Iztapalapa, Comisión Nacional para el Conocimiento y Uso de la Biodiversidad México.

Fay, M.F. 1994. In what situations is in vitro culture appropriated to plant conservation? Biodivers. Conserv. 3:176-183.

Flores-Palacios, A. and S. Valencia-Díaz. 2007. Local illegal trade reveals unknown diversity and involves a high species richness of wild vascular epiphytes. Biol. Conserv. 136:372387.

Gangaprasad, A.N., W.S. Decruse, S. Seeni, and S. Menon. 1999. Micropropagation and restoration of the endangered Malabar daffodil orchid Ipsea malabarica. Lindleyana 14:38-46.

Hernández, J., S. Hernández, and M. Mata. 2001. Regeneración de plántulas a partir del cultivo in vitro de mitades de protocormos de Laelia anceps Lindl. y Catasetum integerrimum Hook. Amaranto. 14:3-12.

Ichihashi, S. 1991. Development of media for aseptic seed germination of Dendrobium. The Bull. Aichi of Education 40:95-100.

IUCN/SSC Orchid Specialist Group. 1996. Orchids - Status survey and action plan. IUCN, Gland, Switzerland, and Cambridge, UK.

Jiménez, M.R., S.L. Sánchez, and J. García-Cruz. 1998. Familia Orchidaceae. Tribu Maxillarieae. Flora del Bajío y de regiones adyacentes. Fascículo 67.

Kerbauy, B.G. and S. Collin. 1997. Increased conversion of root tip meristems of Catasetum fimbriatun into protocorm-like bodies mediated by ethylene. Lindleyana 12:59-63.

Ket, N.V., E.J. Hahn, S.Y. Park, D. Chakrabarty, and K.Y. Paek. 2004. Micropropagation of an endangered orchid Anoectochiuls formosanus. Biol. Plant. 48:339-344.

Knudson, L. 1946. A new nutrient solution for the germination of orchid seeds. Am. Orchid Soc. Bull. 15:214-217.

Kusumoto, M. 1978. Effects of combinations of growth regulating substances, and of organic matter on the propagation and organogenesis of Cymbidium protocorms cultured in vitro. J. Jpn. Soc. Hort. Sci. 47:391-400.
Kusumoto, M. 1979. Effect of combination of growth regulators, and of organic supplements on growth of Cattleya plantlets cultured in vitro. J. Jpn. Soc. Hort. Sci. 47:492-501.

Lee-Espinosa, H.E., A. Laguna-Cerda, J. MurguíaGonzález, P. Elorza-Martínez, L. IglesiasAndreu, B. García-Rosas, F.A. Barredo-Pool, and N. Santana-Buzzy. 2007. Regeneración in vitro de Laelia anceps ssp. dawsonii. Revista Científica UDO Agrícola. 7:58-67.

Mauro, M., D. Sabapathi, and R. Smith. 1994. Influence of benzylaminopurine and alphanaphtalenacetic acid on multiplication and biomass production of Cattleya aurantiaca shoot explants. Lindleyana 9:169-173.

Murashige, T. and F. Skoog. 1962. A revised medium for rapid growth and bioassays with tobacco tissue culture. Physiol. Plant. 15:473494.

Nayak, N.R., S. Patnaik, and S.P. Rath. 1997. Direct shoot regeneration from foliar explant of an epiphytic orchid, Acampe praemorsa (Roxb.) Blatter and McCann. Plant Cell Rep. 16:583-586.

Palacios-Rios, M. and A.P. Flores. 1992. Notas sobre el maquique y cómo afecta su uso a los helechos arborescentes. Boletín de la Asociación Mexicana de Orquideología, A.C. México, D.F. 92:2-5.

Pierik, R.L. and M.H.H. Steegmans. 1972. The effect of 6-benzilaminopurine on growth and development of Cattleya seedlings grown form unripe seeds. Z. Pflanzenphysiol. 68:228-234.

Pierik, R.L.M., P.A. Sprenkles, B. Van Der Harst, and Q.G. Van Der Meys. 1988. Seed germination and further development of plantlets of Paphiopedilum ciliolare Pfitz. in vitro. Scientia Hort. 34:139-153.

Rubluo, A., V.M. Chávez, A. Martínez, and O. Martínez-Vázquez. 1993. Strategies for the recovery of endangered orchids and cacti through in vitro culture. Biol. Conserv. 63 163-169.

Saiprasad, G.V.S. and R. Polisetty. 2003. Effect of growth regulators on production of PLBs and multiple shoots in orchid: Dendrobium 'sonia': Assessment of role of methane and ethylene. Phytomorphology. 53:67-71.

Salazar, G. 1988. Mormodes tuxtlensis, a new species from Veracruz, México. Orq. (Mex.) 11:59-62.

Santos-Hernández, L., M. Martínez-García, J.E. Campos, and E. Aguirre-León. 2005. In vitro propagation of Laelia albida (Orchidaceae) for conservation and ornamental purposes in Mexico. HortScience 40:439-442.

Texeira da Silva, J.A., N. Singh, and M. Tanaka. 2006. Priming biotic factors for optimal protocorm-like body callus induction in hybrid Cymbidium (Orchidaceae), and assessment of cytogenetic stability in regenerated plantlets. Plant Cell. Tiss. Org. Cult. 84:135-144.

Tokuhara, K. and M. Mii. 2001. Induction of embryogenic callus and cell suspension culture from shoot tips excised from flower stalk buds of Phalaenopsis (Orchidaceae). In Vitro Cell. Dev. Biol. Plant 37:457-461.

Wu, I.F., J.T. Chen, and W.C. Chang. 2004. Effects of auxins and cytokinins on embryo formation from root-derived callus of Oncidium 'Gower Ramsey’. Plant Cell. Tiss. Org. Cult. 77:107109 .

Yam, T.W. and M.A. Weatherhead. 1988. Germination and seedling development of some Hong Kong orchids. Lindleyana 3:156-160. 